\section{Sir Robert Mond}

ON Thursday, April 23, Sir Robert Mond was the guest of honour at a luncheon held to congratulate him upon the rank of Commander of the Legion of Honour awarded to him by the French Government. Prof. A. Béhal, president of the Committee of the Maison de la Chimie, Paris, at which the luncheon was held, presented Sir Robert with the insignia of the Order and spoke in the highest terms of his services to science and the human race. He was followed by M. P. Lemoine, director of the Paris Natural History Museum, M. Dussaud, who represented archæologists and M. Jean Vynaud, representing literature; and each speaker expressed appreciation of Sir Robert Mond's scientific work and influence. It is given to few Englishmen to be honoured in this way by French colleagues working in such varying fields of intellectual activity; and we add our congratulations to those expressed at the luncheon upon the distinction just conferred upon one who has long been a generous benefactor to many branches of science in different parts of the world, and has made notable contributions to several of them.

\section{Bust of Michael Faraday}

A BRonze bust of Michael Faraday, by Mrs. Feridah Forbes, has been presented by Sir Robert Hadfield to the Royal Society and now stands in the Society's rooms. It will be recalled that, about the time of the celebration in 1931 of the centenary of the discovery by Faraday of electromagnetic in. duction, Sir Robert produced a work entitled "Faraday and His Metallurgical Researches", which included an account of Faraday's life, of the conditions under which he worked and the men with whom he associated. The Royal Institution, the scene of most of Faraday's labours, has a bust and also a statue of Faraday, but the Royal Society had a portrait only. Sir Robert Hadfield therefore added to the debt which scientific workers already owe him for his memorial volume to Faraday by commissioning Mrs. Forbes to make a bronze bust, which has now been presented to the Royal Society.

\section{Announcements}

Dr. Clarence Smith will deliver a lecture entitled "Modern Chemical Nomenclature" before the Chemical Society on May 14 at 8 p.m. The fifth Pedler Lecture, entitled "Synthesis in Biochemistry", will be delivered before the Society by Prof. R. Robinson on May 28 at 5.30 p.m. Both lectures will be given in the meeting hall of the Institution of Mechanical Engineers, Storey's Gate, Westminster, S.W.1.

THE sixth Congress of German Entomologists will be held at Münden (Hanover) under the presidency of Prof. Hermann Erdnamm on May 27-30. Further information can be obtained from Dr. Walther Horn, Entomologisches Institut, Gosslerstr. 20, BerlinDahlem.
The Marcel Benoit prize of 30,000 francs for the advancement of scientific research has been awarded to Prof. M. Askanazy of Geneva for his pathological investigations on cancer.

During the last two years, the University of Angora has been allotted two million Turkish pounds, more than a quarter of which has been spent on books and instruments. At the present time, eighty-eight professors, of whom half are foreigners, are employed at the University, together with 102 lecturers and 140 assistants.

A course of "Applied Helminthology" with special reference to the control of agricultural and horticultural pests and the internal parasites of farm animals, poultry and gamebirds will be given at the London School of Hygiene and Tropical Medicine, Keppel Street (Gower Street), London, W.C.I, on July 13-31. The lectures will be given by Prof. R. T. Leiper, Dr. T. Goodey, Dr. B. G. Peters and Dr. M. J. Triffitt. Further information can be obtained from the Secretary of the School.

Applications are invited for the following appoint ments, on or before the dates mentioned:

A lecturer in electrical engineering in Cannock Chase Mining College-The Director of Education, County Education Offices, Stafford (May 9).

An assistant master in modern physics at the Dartford Technical College-Mr. F. L. Notley, 11 Essex Road, Dartford (May 9).

An assistant inspector of fisheries (male) in the Department of Agriculture, Dublin-The Secretary, Civil Service Commission, 45 Upper O'Connell Street, Dublin, C.8 (May 11).

A lecturer in anatomy in the University of Cape Town-The High Commissioner for the Union of South Africa, Trafalgar Square, W.C.2 (May 12).

An assistant lecturer in engineering in the Brighton Technical College-The Education Officer, 54 Old Steine, Brighton (May 12).

Scientific officers for food investigation at the Low Temperature Research Station for Research in Biochemistry and Biophysics, Cambridge; the Covent Garden Laboratory; the Torry Research Station, Aberdeen; and the Ditton Laboratory, East Malling -The Establishment Officer, Department of Scientific and Industrial Research, 16 Old Queen Street, Westminster, S.W.1 (May 14).

A professor of botany in the University of Cambridge-The Vice-Chancellor (May 15).

A temporary assistant (Grade III) in the Admiralty Chemical Pool-The Secretary of the Admiralty (C.E. Branch), Whitehall, S.W.1 (quote No. C.E. $5743 / 35$ ) (May 15).

A mechanical and electrical engineer in the Public Works Department of the Government of the Gold Coast-The Crown Agents for the Colonies, 4 Millbank, London, S.W.1 (quote M/4166).

A woman lecturer in psychology, method, etc., in St. Mary's Training College, Poona-Sister Superior, St. Helen's School, Abingdon. 